\title{
Kvalita výuky odborných předmětů a její výzkum s využitím didaktických kazuistik
}

\author{
Pavel Pecina, Peter Marinič
}

\begin{abstract}
Abstrakt: Předložená empirická studie je věnována dosud málo zkoumané oblasti, a to využiti didaktických kazuistik v rámci výzkumu kvality výuky odborných predmètů na střednich školách. Cílem studie je vymezit specifika kvality výuky v podminkách odborného technického vzdèláváni a jeji zkoumáni s využitím didaktických kazuistik. Dále potom prezentace hlavnich zjištèni didaktické kazuistiky realizované ve výuce odborného technického prèrmètu na středni odborné škole technické v Brnè v roce 2019. Metody výzkumu: Ve výzkumu byl aplikován kvalitativni prístup s využitím prípadové studie - didaktické kazuistiky. Výsledky prinášeji informaci o možnosti zkoumáni kvality výuky odborných předmètů s využitím didaktických kazuistik. Dále poskytuji náhled do konkrétni výukové situace a jejího hodnocení. Závéry pomáhaji vymezit a identifikovat zkoumáni kvality výuky ve specifických podminkách výuky odborných technických predmètů.
\end{abstract}

Klíčová slova: kvalita výuky, výzkum kvality výuky, didaktické kazuistiky, didaktické kazuistiky ve výuce odborných predmètu

\section{ÚvoD}

Kvalita výuky je téma, které je v posledních letech v domácích i zahraničních výzkumech velice frekventované. $\mathrm{K}$ dispozici máme v této oblasti jak časopisecké studie, tak monografické práce (Hrmo \& Krpálková, 2010; Janík et al., 2013; Slavík et al., 2017). V podmínkách České republiky se v oblasti zkoumání kvality výuky uplatňují výzkumy procesů výuky, aktivizace žáků, využívání výukových metod a didaktické kazuistiky. Cílem předložené empirické studie je zhodnotit možnosti využití didaktických kazuistik za účelem diagnostiky a zlepšování kvality výuky odborných předmětů na středních školách v České republice. Dále potom prezentovat jednu didaktickou kazuistiku ve výuce odborného technického předmětu, který je vyučován na technické střední škole v Brně.

\section{TEORETICKÁ VÝCHODISKA ŘEŠENÉ PROBLEMATIKY}

Kvalita výuky je rozsáhlé téma, na které lze nahlížet $\mathrm{z}$ různých hledisek a je aktuálním tématem jak pro teoretiky v oblasti pedagogiky, tak pro vedení škol 
i školských zařízení a pro praktikující pedagogy. Jak poukazují Hrmo a $\mathrm{Kr}$ pálková (2010), v obecné rovině je management kvality velmi starou a tradiční oblastí lidské práce a existence. V oblasti vzdělávání se vztahuje její zkoumání ke všem hierarchickým vzdělávacím úrovním i ke všem komponentám procesu výuky (záměry a cíle vzdělávání, obsah vzdělávání, proces vzdělávání, výstupy vzdělávání, podmínky vzdělávání). Do oblasti zkoumání kvality výuky patř́ i otázka toho, co není kvalitní výuka. Odpověd' na tuto otázku opět není jednoduchá, protože nelze uvažovat pouze o výstupech vzdělávání. Autoři se shodují na tom, že diskurs kvality výuky není zcela jednoznačný a je na něj nahlíženo různými úhly pohledu (normativní, analytický, empirický; Janík et al., 2013). Koncepční rámec kvalitě výuky dává realizovaný proces kurikulární reformy a kontinuální snahy o permanentní zlepšování kvality výuky ve všech vzdělávacích stupních a oblastech. Do hry vstupuje i pohled oborových didaktik a jednotlivých oborů. Pomineme hledisko managementu řízení kvality výuky a zaměŕíme se na samotný proces výuky z pohledu jeho kvality. Jako východisko pro zkoumání kvality výuky jsme vyšli $\mathrm{z}$ rámce čtyř věcných okruhů, které jsou koncentrovány ve kvalitě výuky. Dále uvádíme doplněný a upravený pohled na tuto oblast $\mathrm{v}$ podobě čtyř stěžejních oblastí kvality výuky:

- Odpovídající organizace a řízení třídy, využití času, odpovídající tempo, strukturovanost.
- Správné zprostředkování cílů a obsahu výuky - jasnost, strukturovanost, soudržnost.

- Odpovídající systém učebních úloh (kognitivní aktivizace žáků) a odpovídající aplikace výukových technologií (výukové metody, materiální výukové prostředky, zařazení školních i mimoškolních rozvíjejících aktivit žáků). Vhodné propojení, provázanost a proporce teoretické a praktické výuky, vazba vzdělávacích obsahů na aktuální trendy a oblasti daných oborů.

- Vhodné prostředí výuky, podporující klima a atmosféra ve výuce, konstruktivní práce s chybou (Janík et al., 2013, s. 11).

Zajímavý a pro pedagogickou praxi inspirující může být pohled České školní inspekce (2020, s. 52-53). Na základě kritérií hodnocení podmínek, průběhu a výsledků vzdělávání na školní rok 2020/2021 pro středoškolské odborné vzdělávání je kvalitní výuka založena na odpovídajícím dosahování stanovených výukových cílů. Kvalita výuky je podle inspekce koncentrována ve čtyřech věcných, na sebe navazujících pilírích výuky:

- Systematické promýšlení a prííprava výuky v souladu s vědomostmi, dovednostmi a postoji definovanými v kurikulárních dokumentech školy a potřebami žáků.

- Využití širokého spektra výchovně-vzdělávacích postupů a strategií pro naplnění stanovených cílů.

- Systematické sledování vzdělávacích pokroků každého žáka a při plánování a realizaci výuky zohlednění individuálních potřeb žáků.

- Zaměření práce pedagogů na sociální a osobností rozvoj žáků. 
S uvedenými okruhy se pojí další charakteristiky a komponenty: aktivizace, transformace obsahu do podoby jednání ve výuce, systém učebních úloh, řízení třídy, metodická dimenze výuky, využívání času, angažovaný čas, jasnost, střídání činností ve výuce atd. Je zřejmé, že se jedná o rozmanitý systém, který je však třeba nějak uchopit. Jeho nedílnou součástí jsou aktivizující činnosti učitele ve vztahu k žákům, systém výukových metod, který determinuje odpovídající distribuci učebních činností žáků z hlediska dosahování cílů, zprostředkování vzdělávacích obsahů, načasování jednotlivých výukových sekvencí a v neposlední řadě i oblast zajištění odpovídajícího prostředí a atmosféry ve výuce.

\section{KVALITA VÝUKY ODBORNÝCH PŘEDMĚTŮ}

$\mathrm{Z}$ tohoto pohledu není jednoduché vymezit rámec kvality výuky odborných předmětů, protože se této oblasti nevěnuje žádná novější systematická studie. Proto vycházíme z obecnější teorie a př́ibuzných oborů (přírodovědné obory, fyzika). Rámcově lze vyjít z určité normy, podle které je třeba dosahovat u žáků vyšších kategorií cílů, a to v kompetenční rovině. Jak poukazuje Trna (2016), pro kvalitní výuku fyziky je důležité využívání experimentální činnosti a dalších výukových metod zasazených do heuristické výuky (problémově orientovaný rozhovor, demonstrace, pokus, experimentální činnost).

Vaněček (2016) poukazuje na to, jak se do procesu soudobé výuky promíta- jí hlediska a zjištění psychologie učení a pohledy významných psychologických směrů (behaviorismus, nativismus, kognitivismus). $Z$ těchto poznatků vyvozujeme pro specifika výuky technických předmětů následující komponenty kvality výuky: - Východisko potřeb praxe technických oborů a trhu práce, stanovení odpovídajících zdůvodněných cílů výuky v daném rozsahu a úrovni.

- Stanovení odpovídajícího aktuálního obsahu výuky ve vazbě na výukové cíle. Obsah musí reflektovat aktuální stav poznání a požadavky praxe oboru. V otázkách struktury učiva je třeba reflektovat teorii J. S. Brunera, který zjistil, že pokud žáci porozumí struktuře učiva, porozumí i jednotlivým tématům a bude pro ně zapamatování učiva snazší (Bruner, 1966).

- Systém výukových činností učitele, sekvence jednotlivých fází a etap výuky, strukturovanost, odpovídající časové sekvence, aplikace vhodných výukových metod, forem a prostředků výuky. Vhodné a podnětné prostředí výuky.

- Odpovídající hodnocení žáků, zpětná vazba.

Všechny tyto komponenty je třeba zasadit do rámce kvalitní prípravy výuky, pro který je východiskem odpovídající odborná erudice učitele daného odborného předmětu. Soudobé didaktické teorie zdůrazňují význam zprostředkování vzdělávacích obsahů a sdílení zkušeností v oblasti výuky např́íc obory (transdisciplinární př́stup).

Významným syntetizujícím a vizualizujícím prvkem $\mathrm{v}$ oblasti zkoumání 
kvality výuky je její modelování (modely kvality výuky). Ty vychází z modelů kvality školy a vzdělávacího systému a umožňují vidět jednotlivé prvky kvality ve vzájemných souvislostech a návaznostech. Modely kvality výuky se zaměřují na vyučování a učení v rámci vyučovacího procesu a s ním související proměnné. $\mathrm{V}$ posledních padesáti letech vznikla řada modelů, z nichž zmíníme několik vybraných. Prvním modelem školního učení byl Carrollův model (1963). Dále vznikl Walbergův model (1980), Helmkeho model (2007), Fendův model (2008), model Starého a Chvála (2009) a modely v rámci několika studií se zaměřením na předměty školního vzdělávání, např. matematiku a fyziku (model školního vzdělávání uplatněný ve studii TIMSS, model kvality výuky uplatněný ve videostudii IPN, model kvality výuky uplatněný ve studii Pythagoras). Jednotlivé modely pracují s různými faktory (faktor času k vyučování a učení, psychologické faktory učení, mikro a makro faktory, nabídka vyučování, nabídka učení) a uvádí je do relačních vztahů. Fendův model je pokusem o zachycení školského systému jako celku. Uvádí pět rovin jednání: vzdělávací politika, vzdělávací zpráva, škola, vyučování a výuka, žáci (Fend, 2008, s. 36-37). Za obecné východisko pro aplikaci na podmínky odborného technického vzdělávání můžeme považovat novější model Starého a Chvála (2009). Ten zdůrazňuje významnou roli evaluačních nástrojů pro monitoring výstupů vzdělávání (tamtéž, s. 66). Dalším novějším modelem kvality výuky je model podle Helmkeho, který dále uvádíme v modifikované podobě (obr. 1). Tento model vychází z myšlenky vyučování jako př́ležitosti $\mathrm{k}$ učení, preferuje tedy procesuální rovinu. $Z$ výše uvedených se nám jeví jako vhodný pro aplikaci na podmínky odborného technického vzdělávání, protože se pokouší o komplexní integraci všech důležitých proměnných kvality výuky. Původní model podle Helmkeho jsme doplnili o některé aspekty, které se vztahují k cílovým kategoriím, obsahu vzdělávání a technologii výuky (vztah teorie a praxe $\mathrm{v}$ technickém vzdělávání, mimoškolní vzdělávací procesy, schopnosti dalšího vzdělávání, evaluační nástroje). Ve shodě $s$ autorem považujeme za jádro kvality výuky v užším pojetí ty aspekty, které jsou uvedeny ve druhém sloupci (vyučování). V kontextu odborného technického vzdělávání je významná oblast spolupráce s odborníky daných oborů odborného vzdělávání, začlenění mimoškolních akcí relevantních $\mathrm{k}$ daným oborům. $S$ ohledem na dynamiku vývoje technických i ekonomických věd je důležitá účast učitelů na dalším vzdělávání (sebevzdělávání, kurzy, pracovní stáže apod.).

\section{VÝZKUMY KVALITY VÝUKY - DIDAKTICKÉ KAZUISTIKY}

$\mathrm{V}$ současné době máme $\mathrm{k}$ dispozici dvě monografických studií, které v podmínkách České republiky zkoumají kvalitu výuky prostřednictvím didaktických kazuistik - Janík el al. (2013) a Slavík et al. (2017). V obou př́padech se jedná o rozsáhlé studie, jež jsou dílem řady autorů, kteří se podíleli na zpracování 
Kontext tř́dy a kontext oboru, specifika obsahu vzdělávání, učivo, evaluační nástroje

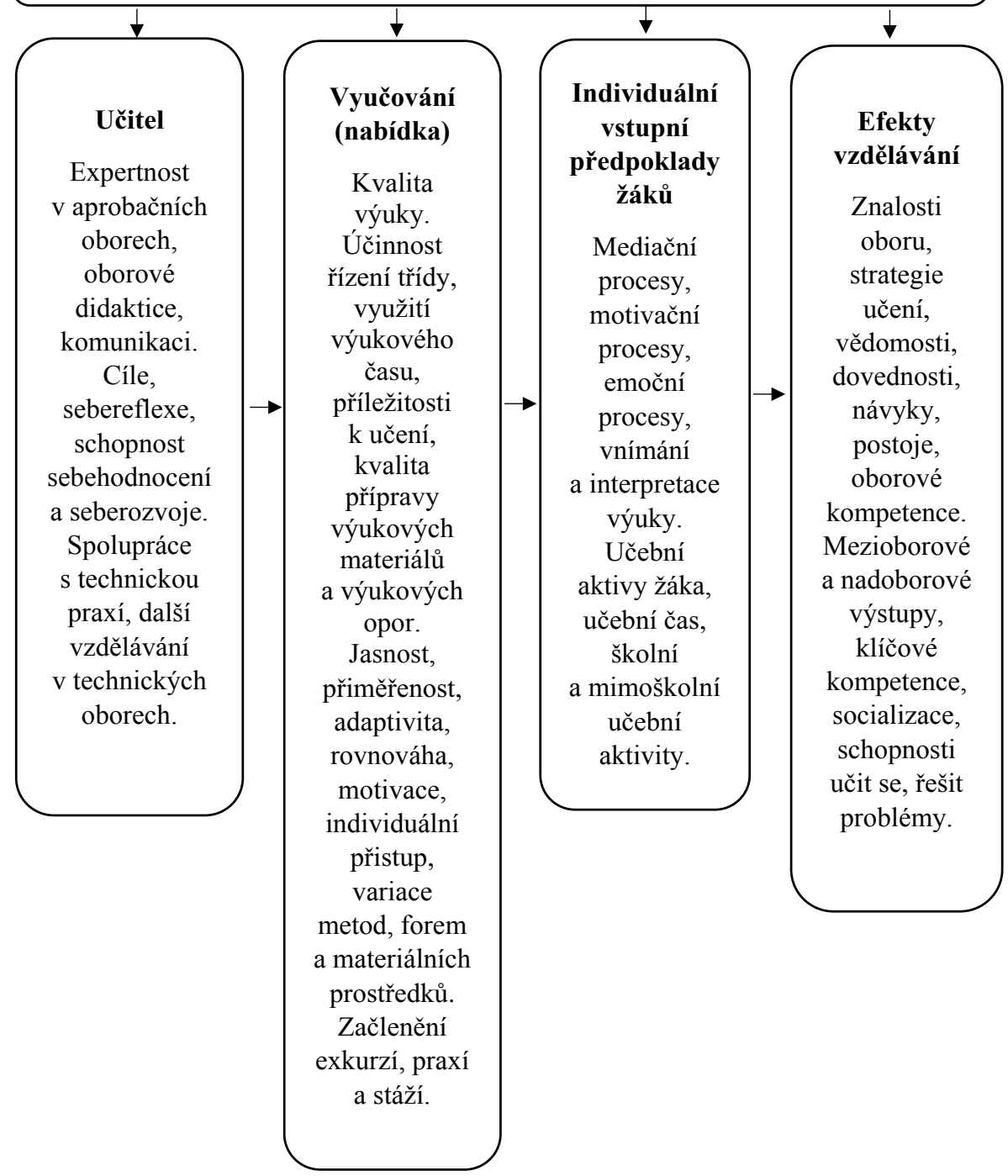

Obr. 1 Model kvality výuky (upraveno podle Helmke et al., 2007, s. 42) 
teorie $\mathrm{k}$ dané problematice i na zpracování didaktických kazuistik vybraných oborů školního vzdělávání. Ze zahraničních studií k problematice didaktických kazuistik zmíníme práci Davisové a Wilcockové (2003) a Beatyho (1999). Výzkum kvality výuky odborných předmětů $s$ využitím didaktických kazuistik se v České republice zatím formuje. Je třeba se inspirovat zahraničními výzkumy, které jsou $\mathrm{v}$ řadě zemí v této oblasti bohaté a institucionalizované (Německo, Finsko, Švédsko i Slovensko). Relevantní přehled zahraničních výzkumů odborného vzdělávání uvádí Průcha (2019). V oblasti pozorování výuky a využití didaktických kazuistik je možné zmínit švédskou studii Fjellströma (2014), který zjištoval proces učení ve stavebním programu na švédské střední škole. Německé výzkumy jsou realizovány nap̌r. centry BIBB (Bundesinstitut für Berufsbildung) a IBT (Institut Technik und Bildung). Německé výzkumy odborného vzdělávání mají mnoho témat, mimo jiné výzkum propojení odborného vzdělávání ve školách a podnicích (duální systém), dále potom výzkumy hybridního vzdělávání. Přínosem německého výzkumu je rozsáhlá studie (Rauner \& Maclean, 2009), která věnuje velký prostor odbornému technickému vzdělávání. Obsahem studie je mimo jiné výzkum procesů učení (mikroúroveň) v odborném technickém vzdělávání. Další výzkumy byly realizovány ve Finsku, Nizozemí, Dánsku a Anglii (Průcha, 2019; Michelsen \& Sternström, 2017). Zajímavým mezinárodním projektem zjištujúí́m kvalitu výuky ve strojírenských oborech ve vztahu $\mathrm{k}$ trhu práce je
QualiVET. Na projektu se podílelo celkem sedm států Evropské unie (Německo, Velká Británie, Španělsko, Nizozemsko, Slovinsko, Rakousko, Česká republika). Výstupy projektu jsou publikovány ve studii (Blings \& Gessler, 2007). Vznikl také rámec rozvoje kvality QualiVET pro školy se strojírenským zaměřením (Michek, 2007).

V této části vymezíme základní rámec a př́nos didaktických kazuistik jako východisko pro jejich aplikaci na podmínky zkoumání kvality výuky odborných předmětů.

Př́padová studie (také kazuistika, angl. case study) jako jedna z metod kvalitativního výzkumu umožňuje detailní studium jednoho př́padu za účelem aplikace získaných poznatků pro porozumění př́padům obdobným. Studiem kazuistik má smysl se zabývat, protože se lze poučit o tom, jakého charakteru jsou určité dominanty v konkrétním oboru, jaké se zde odehrávají procesy a úkony, jak fungují určité praktiky apod. Jak poukazuje Jan Slavík, didaktické kazuistiky jsou typické pro tzv. klinické vědy, pro které je profesní praxe velmi důležitou dimenzí. Klinickými vědami jsou kromě např. lékařských věd a právních věd také pedagogika a didaktika (Slavík et al., 2017).

Didaktické kazuistiky mohou reprezentovat profesní zkušenost, a to v širším záběru v dané oblasti (oboru, předmětu), ve vzájemných proměnách a v systému výukových situací. Proto mohou přinášet zdroje pro odhalování nových kvalit praktické zkušenosti a podněty pro řešení nejrůznějších výukových problémů vzdělávací praxe. Jedná 
se o konkrétní jedinečné reprezentace určitých situací, které poskytují vhled do konkrétního problému ve výuce. $\mathrm{Z}$ pohledu výuky konkrétních oborů kazuistika přináší reálnou reprezentaci kompletního praktického problému v rámci daného oboru. Jde o reprezentaci reálné profesní zkušenosti $\mathrm{v}$ reálné praxi, a to je velmi významné. $\mathrm{V}$ informačních pramenech se $\mathrm{v}$ této souvislosti setkáváme s pojmem amalgamace znalostí nebo také zhuštování znalostí (Bromme, 2008; Slavík et al., 2017). Amalgamace přitom znamená jednak „zhuštění“ nebo „splynutí", ale také získání něčeho nového, tedy nových znalostí.

V současné době máme $\mathrm{k}$ dispozici kazuistiky $\mathrm{v}$ rámci výuky vybraných oborů školního vzdělávání (všeobecně vzdělávací předměty: matematika, fyzika, český jazyk a cizí jazyky, zeměpis, biologie, dějepis, výtvarná výchova, tělesná výchova). Tyto kazuistiky vychází z aplikace metodiky 3A a rozvíjejících hospitací a hospitačních videostudií, což je relevantní prostředek k poznávání a posuzování procesů výuky $\mathrm{z}$ hlediska obsahově zaměřeného prístupu ke zkoumání kvality výuky (Slavík et al., 2017). Bohužel, zatím chybí kazuistiky v oblasti výuky technické výchovy (praktických činností) na základních školách a v oblasti výuky odborných předmětů na středních odborných školách.

\section{DIDAKTICKÉ KAZUISTIKY}

\section{VE VÝUCE ODBORNÝCH PŘEDMĚTŮ}

$\mathrm{V}$ této části prezentujeme výsledky jedné ze tř̌i didaktických kazuistik, které dosud nebyly nikde publikovány a jsou za- měřeny na výuku odborných technických předmětů na středních školách. Cílem dále uvedené kazuistiky je zhodnotit úroveň dané konkrétní výukové situace a navrhnout alteraci $\mathrm{k}$ dané situaci. Stanovili jsme základní výzkumnou otázku: Jaká je úroveň výukové situace zaznamenané vyučovací jednotky? Pro nalezení odpovědi byla uplatněna metodika 3A (anotace, analýza, alterace). Byl použit dostupný výběr (dotčený učitel byl jedním ze dvou učitelů spolupracujících škol, který byl ochoten se do výzkumu zapojit).

\section{Anotace}

Zde prezentovaná hodina je aplikována v rámci výuky učebního oboru 23-68-H/01 Mechanik opravár motorových vozidel $\mathrm{v}$ rámci vzdělávacího modulu „Motory“. Jedná se tedy o specifickou organizační jednotku v rámci modulové výuky. Vyučovací hodina byla realizována na střední odborné škole technické v Brně, a to dne 11. 4 2019, jako druhá vyučovací hodina, tedy od 8:55 do 9:40 v počtu 24 žáků, všichni chlapci. Hodinu přednesl učitel odborných předmětů J. R. (iniciály jsou smyšlené, učitel si nepřál být jmenován). Jedná se o učitele s pedagogickou praxí 25 let (učitel expert), který má odborné strojírenské vzdělání rozšířené akreditovaným kurzem doplňujícího pedagogického studia učitelství odborných předmětů.

Vyučovací hodina byla zaznamenána na diktafon, poté přepsána do písemné podoby a podrobně analyzována. Kazuistika byla zpracována autory této studie. 
Hlavní autor studie byl př́tomen ve výuce a zaznamenal její průběh na diktafon. Učitel odborného předmětu poskytl další podklady k jejímu zpracování (příprava výuky). Výuka proběhla ve tř́dě učebního oboru mechanik-opravář motorových vozidel (24 žáků). S učitelem byl proveden předhospitační pohovor, ve kterém byla konzultována dále uvedená př́íprava a plán výukové jednotky. Také bylo zjištěno, že se jedná o třídu žáků, jejichž celkové průměrné hodnocení z odborných modulů odpovídá klasifikaci „dobrý“. Podle učitele se tedy jedná o průměrnou trrídu $\mathrm{z}$ hlediska schopností i znalostí.

Dále uvádíme písemnou př́ípravu, kterou měl vyučující připravenu pro potřeby výuky této konkrétní vyučovací jednotky. $\mathrm{V}$ př́loze potom uvádíme autentické podklady pro výuku vzdělávacího modulu „Motory“ (tab. 1 a 2) tak, jak je uveden ve školním vzdělávacím programu, a také autentický podrobný přepis nahrané vyučovací jednotky, na který se odkazujeme.

\section{Př́íprava na vyučování / Autome- chanik}

2. ročník, modul Motory

Č́slo vyučovací hodiny: 16

Téma vyučovací hodiny: válce motoru, konstrukce, rozměry a třídění

Cíl vyučovací hodiny: naučit účel a požadavky na válce, rozdíly konstrukce válců a vložek válců, jejich montáž, měrení a kontrolu

Použité pomůcky: učebnice Motory (3), připravené obrázky na počítači, projektor a konkrétní vložky válců (pomůcky)
Forma výuky: ve třídě, v lavicích, celá tř́da (25 žáků) sleduje a diskutuje $s$ vyučujícím, který vede hodinu převážně od tabule, žáci sledují, ptají se a zapisují si důležité body

Struktura hodiny:

- Zahájení - Pozdrav a stručný nástin tématu hodiny, príprava a kontrola poznámkových sešitů a učebnic, prezence a zápis hodiny do počítače.

- Motivace - Co je potřeba vědět o konstrukci a funkci válců motoru, jejich kontrole a montáži.

- Evokace - Zjištění předchozích zkušeností s opravami a poruchami válců motoru.

- Opakování - Cyklus čtyřdobého zážehového motoru podle promítnutého obrázku.

Uvědomění:

- Válce motoru jsou obvykle umístěny v bloku motoru a spolu $s$ hlavou a pístem tvoří spalovací prostor.

- Zachytávají tlaky a odvádějí teplo ze spalovacího prostoru.

- Mohou být chlazeny vzduchem, nebo kapalinou.

- Jsou vytvořeny přímo $\mathrm{v}$ bloku, pokud je litinový, bez úpravy, lze provádět výbrus (tř̌i po $0,25 \mathrm{~mm}$ ). U hliníkových bloků povrchově upraveny metodou Nikasil, Alusil, plazmovým nástřikem, chemicky. Litinové vložky jsou zalisovány jako suché prrímo $\mathrm{v}$ bloku, př́padně vloženy jako mokré a utěsněny, montovány $s$ přesahem.

- Postup měření, trrídění válců do skupin.

- Montáž a povrchová úprava honováním. 
- Ukázka povrchových úprav na praktických pomůckách, diskuse o správných rozměrech pístů pro jednotlivé třídy válců $\mathrm{A}, \mathrm{B}, \mathrm{C}$ (pro nové motory). Upozornění na opravárenské rozměry výbrusů a opravárenských pístů.

- Možnosti demontáže poškozených vložek z bloku.

Reflexe:

- Shrnutí učiva, kontrolní otázky a zakončení vyučovací hodiny.
$\mathrm{Z}$ uvedeného je patrné, že řešené téma patř́ do tematického celku „3. Konstrukce, diagnostika a opravy“. V předešlé hodině byl probírán čtyřdobý spalovací motor.

\section{Analýza}

Výše je uvedena klasická rámcová písemná př́íprava na výuku, která obsahuje vybrané didaktické náležitosti (identifikační údaje, cíle hodiny, pomůcky,

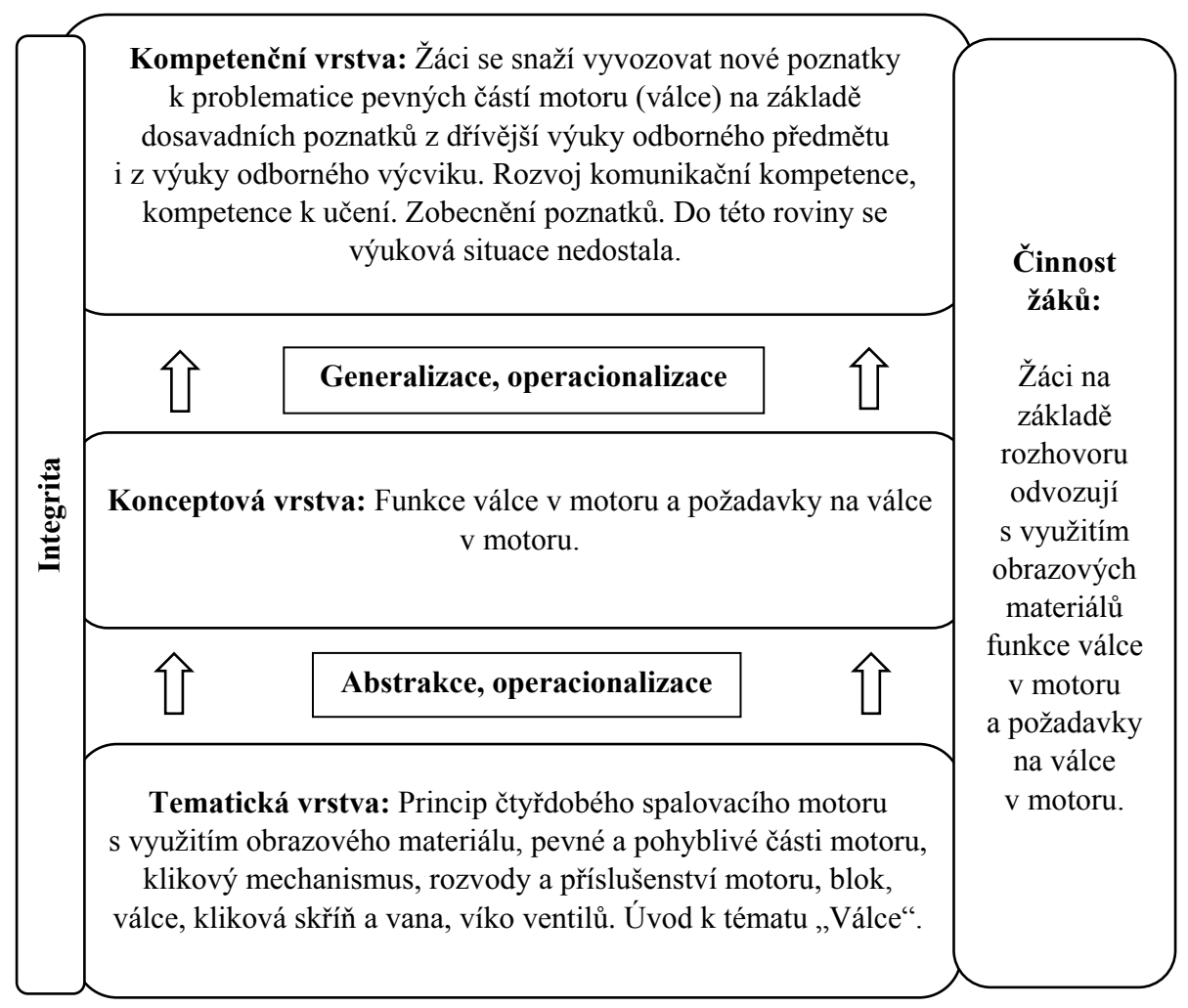

Obr. 2 Konceptový diagram - válce motoru, konstrukce, rozměry a tř́ídění 
strukturu hodiny, použitá technologie výuky, rámcově zpracované učivo). Př́íprava tedy obsahuje jak část metodickou (cíle, pomůcky, organizace výuky, metody výuky), tak část obsahovou (uchopení učiva a jeho ztvárnění do vzdělávacího obsahu). Stanovení výukového cíle jeví rezervy (nesprávná formulace cíle). Navíc cíl je podle taxonomií cílů formulován pro nižší kategorie (znalost, pochopení). Cíl neobsahuje rovinu psychomotorickou a afektivní.

\section{Rozbor transformace obsahu}

$\mathrm{Z}$ vědeckého hlediska je obsah výuky $\mathrm{v}$ pořádku, což jsme ověrili komparací $s$ věrohodným odborným zdrojem (kolektiv autorů, 2010).

Strukturu výše zaznamenané výukové situace ilustrujeme $s$ využitím konceptového diagramu (obr. 2).

Učitel při zprostředkování vzdělávacího obsahu použil výklad (vysvětlování, popis) a rozhovor s využitím vybraných pomůcek (učebnice, obrázky, části motoru). Z tohoto hlediska je výuková situace relativně chudá. Tematická vrstva (viz výše) je prezentována přehledem pojmů, které reprezentují jednotlivé části motoru. Posun ke konceptové vrstvě demonstruje odvození funkce válce v motoru a požadavky na ně. Problém nastal při přechodu na kompetenční vrstvu. Učitel se zaměroval na oborový obsah a aktivizoval žáky s pomocí rozhovoru. Řizené objevování se však nevyskytuje, i když to téma vhodně umožňuje. Autor se pokusil o frontální konstruktivistickou výukovou situaci s využitím modelu E-U-R (evokace - uvědomění - reflexe), což se mu podařilo ve všech fázích pouze zčásti.

\section{Alterace}

Tato část má hlavní význam ve vztahu k hodnocení kvality výuky a jejím zlepšování. Alterace znamená posoudit kvalitu výukové situace podle následujících úrovní (Janík et al., 2013, s. 234):

- situace selhávající,

- situace nerozvinutá,

- situace podnětná,

- situace rozvíjející.

$\mathrm{Na}$ základě vyhodnocení situace je navržena zlepšující alterace $s$ ohledem na zprostředkovaný vzdělávací obsah. Dále je navržená alterace kriticky posouzena za účelem objektivního objasnění, v čem je lepší a jiná. Součástí této části je i úvaha o tom, proč učitel alteraci nepoužil, což může mít mnoho příčin (nedostatek času, nevhodná atmosféra, neznalost relevantní technologie výuky $\mathrm{v}$ kontextu vzdělávacího obsahu apod.).

Z uvedené zaznamenané vyučovací hodiny je patrné, že se jednalo o př́klad tradiční frontální výuky. Učitel použil metodu výkladu v kombinaci s názorem, dále potom rozhovor. $V$ průběhu celé vyučovací jednotky se snažil žáky aktivizovat a navázat na jejich dosavadní vědomosti. Bohužel nebyly využity žádné pracovní listy ani práce ve skupinách. Prŕstup učitele $k$ výuce lze označit jako tradiční se snahou žáky aktivizovat a zapojit do aktivní učební činnosti. První možnou alterací je použití pracovních listů pro žáky, kde by měli připravené obrazové materiály, plnili připravené úlohy a podle potřeb si zapisovali důležité informace $\mathrm{z}$ výkladu do pracovních listů. Využít by bylo možné např. i mentální 
mapování (myšlenkové mapy) v př́ípadě funkcí a požadavků na válce. Dané téma je vhodné i pro aplikaci badatelsky orientované výuky, tedy výuky, kdy budou žáci řešit problémové úkoly zaměřené na objevení částí a funkcí motoru s využitím odpovídajících materiálů a dokumentace. Celou výukovou situaci lze hodnotit jako podnětnou, avšak nerozvíjející. Žáci byli sice aktivní, avšak vyskytla se samočinnost, práce podle vzoru (opisování z učebnice - viz účel válců). Ve vyučovací hodině také chybí zopakování důležitých informací a zhodnocení práce $\mathrm{v}$ hodině. Celkově lze konstatovat, že by bylo možné zasadit celou výukovou situaci do heuristické (objevné) výuky s využitím odpovídajících obrazových materiálů a navodit badatelské aktivity žáků. Tím by bylo možné realizovat výuku, která z hlediska kvality výuky umožňuje rozvoj kompetenční vrstvy. $\mathrm{Z}$ hlediska obsahu výuky by bylo možné propojit činnosti $s$ objevováním a propojováním poznatků a $s$ generalizací v souvislosti s dalšími poznatky, jako jsou vztah objemu motoru a jeho vliv na výkon motoru, otáčky motoru, počet válců, vstřikování, třecí síly, převody a další.

Další možný návrh alterace spočívá ve využití virtuální reality. Lze vytvořit nebo využít vhodný dynamický obraz (animace činnosti spalovacího motoru), který by bylo možné zasadit do expoziční fáze výuky tak, aby byli žáci vedeni $\mathrm{k}$ řízenému objevování nových poznatků k tématu. Nabízí se také možnost využití 3D zobrazení motoru jako celku i jednotlivých jeho částí, a to v organické provázanosti s heuristickou výukou.
S učitelem byl po zpracování kazuistiky realizován pohospitační rozhovor, ve kterém byly konzultovány navržené alterace. Učitel se $\mathrm{k}$ celé situaci postavil kladně a naznal možnost dané téma vyučovat $\mathrm{v}$ modifikované podobě.

Celkově lze konstatovat, že snaha učitele byla udělat výukovou situaci co nejkvalitnějšś, i když se to podařilo jen částečně. Je zřejmé, že danou koncepci považoval za správnou. $\mathrm{V}$ jeho možnostech, schopnostech i zkušenostech by bylo alterace aplikovat v plném rozsahu (jedná se o učitele experta s dlouholetou pedagogickou praxí nad deset let).

\section{ZÁVĚR}

Analyzovanou výukovou situaci jsme shledali jako podnětnou, ale ne rozvíjející. Následné alterace mohou posloužit $\mathrm{k}$ jinému náhledu na možnou realizaci dané výukové situace z pohledu požadavků na kvalitu výuky. Zajímavý bude i pohled jiného učitele odborného předmětu stejného zaměření na danou výukovou situaci. Podařilo se nám zapojit učitele stejného technického zaměření ze střední technické školy v Kroměříži. $S$ učitelem je naplánován rozhovor, jehož výstup bude předmětem naší další práce v této oblasti.

Výše popsaná teorie a didaktická kazuistika může být výchozím bodem pro další zkoumání procesu výuky odborných předmětů $\mathrm{z}$ pohledu kvality výuky $\mathrm{s}$ využitím didaktických kazuistik. Kromě prezentované kazuistiky máme připraveny další dvě kazuistiky, které budou $\mathrm{v}$ plném rozsahu prezentovány $\mathrm{v}$ dalších 
připravovaných publikacích. Kromě toho máme v plánu zpracovat další kazuistiky, které pokryjí alespoň hlavní oblasti výuky odborných technických předmětů (elektrotechnika, strojírenství, informatika, sta- vebnictví, oblast chemicko-technologická, dřevozpracující obor). V další práci se plánujeme zaměrit také na výuku ekonomických předmětů a oborů obchodu a služeb.

\section{LiteratURA}

Beaty, L. (1999). Supporting learning from eperience. In H. Fry, S. Ketteringe \& S. Marshall (Eds.), A handbook for teaching and learning in higher education (s. 134-147). Glasgow: Kogan Page.

Blings, J., \& Gessler, M. (Eds.). (2007). Quality development and quality assurance with labour market reference for the vocational education and training system in the metal sector. Results from the European Leonardo Project QualiVET. Analysis reports from Austria, Czech Republic, Germany, Netherlands, Slovenia, Spain and United Kingdom. Bremen: Perspektiven-Offset-Druck.

Bromme, R. (2008). Pedagogical contens knowledge jako konceptuální východisko pro výzkum moudrosti praktiků. In. T. Janík et al., Metodologické problémy výzkumu didaktických znalostí obsahu (s. 9-16). Brno: Paido

Bruner, J. S. (1966). Toward a theory of instruction. New York: W. W. Norton.

Carroll, J. B. (1963). A model of school learning. Teachers College Record, 64(8), 723-733.

Davis, C., \& Wilcock, E. (2003). Teaching materials using case studies. Liverpool: The UK Centre for Materials Education.

Česká školní inspekce. (2020). Kritéria hodnocení podminek, průběhu a výsledkủ vzdělávání na školni rok 2020/2021. Dostupné z www.csicr.cz/cz/Kvalitni-skola

Fend, H. (2008). Schule gestalten: Systemsteuerung, Schulentwicklung und Unterrichtsqualität. Wiesbaden: VS Verlag.

Fjellström, M. (2014). Vocational education in practice: A study of work-based learning in a construction programme at a Swedish upper secondary school [Odborné vzdělávání v praxi: Studium pracovního učení ve stavebním programu na švédské stř̌ední škole]. Empirical Research in Vocational Education and Training, 6(2).

Helmke, A. et al. (2007). Der Ratingbogen der DESI-Videostudie. Dostupné z www.uni-landau.de Hrmo, R., \& Krpálková, K. (2010). Zvyšovanie kvality vyučovacieho procesu. Bratislava: Slovenská technická univerzita.

Janík, T., Slavík, J., Mužík, V., Trna, J., Janko, T., Lokajičková, V., ... Zlatníček, P. (2013). Kvalita (ve) vzděláváni obsahově zaměrenený prístup ke zkoumáni a zlepšováni výuky. Brno: Masarykova univerzita.

Kolektiv autorů. (2010). AUTOMOBILY, motory (3). Brno: AVID.

Michek, S. (Ed.). (2007). Rozvoj kvality odborného vzdělávání v Evropee. Praha: Národní ústav odborného vzdělávání. 
Michelsen, S., \& Sternström, M. L. (2017). Vocational education in the Nordic countries: The historical evolution. London: Routledge

Průcha, J. (2019). Odborné školstvi a odborné vzděláváni: Fungování systému, problémy praxe a výzkum. Praha: Wolters Kluwer.

Rauner, F., \& Maclean, R. et al. (2009). Handbook of technical and vocational education and training research. New York: Springer.

Slavík, J., Janík, T., Najvar, P., \& Knecht, P. (2017). Transdisciplinární didaktika: O učitelském sdíleni znalostí a zvyšováni kvality výuky napríč obory. Brno: Masarykova univerzita.

Starý, K., \& Chvál, M. (2009). Kvalita a efektivita výuky: metodologické př́stupy. In M. Janíková, K. Vlčková et al. (2009), Výzkum výuky: Tematické oblasti, výzkumné prístupy a metody. Brno: Paido.

Trna, J. (2016). Fyzika: Záhadná setrvačnost těles v jednoduchých experimentech. In T. Janík et al., Kvalita (ve) vzdèláváni obsahově zaměrený prístup ke zkoumáni a zlepšováni výnky. Brno: Masarykova univerzita.

Vaněček, D. et al. (2016). Didaktika technických odborných predmětů. Praha: ČVUT.

Walberg, H. J. (1980). A psychological theory of educational productivity. In F. H. Farley \& N. J. Gordon (Eds.), Psychology in education (s. 81-110). Berkeley: McCutchan.

Mgr. Pavel Pecina, Ph.D.

Masarykova univerzita, Pedagogická fakulta, Katedra fyziky, chemie a odborného vzdèláváni; e-mail:ppecina@ped.muni.cz

Ing. Peter Marinič, Ph.D.

Masarykova univerzita, Pedagogická fakulta, Katedra fyziky, chemie a odborného vzdèláváni; e-mail:marinic@ped.muni.cz

\section{PECINA, P., MARINIČ, P. Specific Issues of the Implementation of Inter- vention Programmes to Support the Development of Pre-literacy Skills}

The empirical study presented here is devoted to a hitherto little-researched area, that of using didactic case studies for research on the quality of the teaching of vocational subjects in secondary schools. The aim of the study is to define the specifics of the quality of teaching in the conditions of technical vocational education and research into that using didactic case studies. Furthermore, we present the main findings from a didactic case study realised in the teaching of a technical vocational subject at a secondary technical school in Brno in 2019. Research methods: A qualitative approach was applied in the research using a didactic case study. The results provide information about the possibility of ex- 
amining the quality of the teaching of technical vocational subjects using didactic case studies and also provide insights into the specific educational situation and its evaluation. The conclusions help to define and identify the examination of the quality of the teaching of technical vocational subjects.

Keywords: quality of teaching, research on the quality of teaching, didactic case study, didactic case study in teaching vocational subjects

\section{Př́́LOHA}

\section{Předmět: Motory}

Obor vzdělání: 23-68-H/01 Mechanik opravář motorových vozidel

ŠVP: Automechanik

Ročník: druhý

Platný pro tř́ídu: 2. A, 2. B

Zpracoval: Ing. J. R.

Vyučující: Ing. J. R.

Platný pro školní rok: 2018/2019

Dostupné z webových stránek Integrované střední školy automobilní Brno: https:// issabrno.cz/wp-content/uploads/2018-svp-automechanik.pdf

Přepis hodiny učebního oboru Automechanik 23-68-H/01 Mechanik opravář motorových vozidel, druhý ročník, modul Motory podle přiloženého tematického plánu (tab. 1 a 2$)$

Hodina proběhla dne 11. dubna 2019 jako druhá vyučovací, tedy od 8:55 do 9:40, $\mathrm{v}$ učebně č. $10 \mathrm{v}$ počtu 24 žáků, všichni chlapci.

16. hodina modulu $=$ Téma: Pevné části motoru. Válce.

Touto vyučovací hodinou je zahájen konstrukční popis motoru. $\mathrm{V}$ předcházejících hodinách se vyučující věnoval činnosti spalovacích motorů, a proto vždy na začátku hodiny opakoval podle promítaných obrázků základy spalovacího cyklu, poprípadě P-V diagram a kruhový diagram časování. Při výuce byl používán projektor $s$ počítačem a připravené modelové pomůcky válců pro názornější představu.

Dále uvádíme přepis záznamu vyučovací hodiny:

8:55: Př́íchod do učebny, pozdrav, zběžná kontrola pomůcek, přihlášení do počítače a zápis hodiny do evidence včetně absence.

9:00 Ucittel: „Nejprve někdo popíše promítnutý cyklus čtyřdobého zážehového motoru. Pojdte k tabuli a povídejte." (Ukáže na jednoho žáka) „Není to zkoušení na známky, je to nácvik samostatného projevu. Tak popište první část.“ 
Tab. 1 Základní informace o vzdělávacím modulu „Motory“

\begin{tabular}{|c|c|c|c|}
\hline \multirow{2}{*}{ Název modulu: } & \multirow{2}{*}{ MOTORY } & \multirow{2}{*}{$\begin{array}{l}\text { Kód modulu: } \\
\text { Platnost od: }\end{array}$} & \multirow{2}{*}{\begin{tabular}{|l|} 
AM.II.8-K168 \\
1.9 .2012 \\
\end{tabular}} \\
\hline & & & \\
\hline \multirow{2}{*}{ Časová dotace } & & 2 & \\
\hline & & & \\
\hline & \multicolumn{3}{|c|}{$\begin{array}{l}\text { cích motorů, jejich částí, konstrukce, } \\
\text { lerních a alternativních koncepcí. }\end{array}$} \\
\hline & \\
\hline \multicolumn{4}{|c|}{$\begin{array}{l}\text { Předpokládané výsledky vzdělávání: } \\
\text { Žák zná konstrukci a princip činnosti zážehových a vznětových motorů a ovládá montáž } \\
\text { a demontáž hnacích agregátů motorových vozidel, údržbu, opravy, seřizení a měrení pevných } \\
\text { i pohyblivých částí spalovacích motorů používaných v silničních motorových vozidlech. }\end{array}$} \\
\hline \multicolumn{4}{|c|}{$\begin{array}{l}\text { Obsah modulu: } \\
\text { - rozdělení spalovacích motorů, problematika hybridních pohonů } \\
\text { - základní pojmy, základní požadavky bezpečnosti při práci na vozidlech s vysokým napětím } \\
\text { - akumulátorů } \\
\text { - princip činnosti pístových spalovacích motorů, zvláštnosti motorů spolupracujících s elektro- } \\
\text { - rozvody } \\
\text { - pevné části motoru } \\
\text { - klikové ústrojí } \\
\text { - přeplňování spalovacích motorů } \\
\text { - diagnostika a opravy motorů }\end{array}$} \\
\hline \multicolumn{4}{|c|}{$\begin{array}{l}\text { Doporučené postupy výuky: } \\
\text { Teoretická a praktická výuka probíhá v úzké návaznosti probíraných témat tak, aby si žáci mohli } \\
\text { získané vědomosti následně ověrit při praktických činnostech na různých druzích spalovacích } \\
\text { motorů. }\end{array}$} \\
\hline \multicolumn{4}{|c|}{$\begin{array}{l}\text { Kritéria hodnocení: } \\
\text { - znalost základních pojmů, rozdělení, druhů, konstrukce a principu činnosti spalovacích } \\
\text { motorů } \\
\text { - orientace v alternativních pohonech motorových vozidel } \\
\text { - demontáž a montáž motorů } \\
\text { - kontrola, diagnostika, údržba, nastavení a opravy spalovacích motorů a jejich částí } \\
\text { - generální opravy a renovace motorů }\end{array}$} \\
\hline \multicolumn{4}{|c|}{$\begin{array}{l}\text { Postupy hodnocení: } \\
\text { Základním kritériem hodnocení je znalost konstrukce a principu činnosti s } \\
\text { současně s prováděním oprav závad, které se na spalovacích motorech vyskytuj } \\
\text { a nastavení rozvodů, výměna těsnění atd.). }\end{array}$} \\
\hline \multicolumn{4}{|c|}{$\begin{array}{l}\text { Doporučená literatura: } \\
\text { AUTOMOBILY } 3 \text { - Motory, Ing. Zdeněk Jan }\end{array}$} \\
\hline
\end{tabular}


Tab. 2 Cíle a učivo vzdělávacího modulu „Motory“ (modul č. 8: Motory, 2. ročník, odborná teorie 42 hodin)

\begin{tabular}{|c|c|c|}
\hline Výsledky vzdělávání a kompetence & Tematické celky & Hodiny \\
\hline $\begin{array}{l}\text { Žák: } \\
\text { - zná základní druhy spalovacích motorů } \\
\text { a možnosti jejich použití }\end{array}$ & $\begin{array}{l}\text { 1. Rozdělení spalovacích motorů, } \\
\text { základní pojmy, alternativní paliva } \\
\text { a hybridní pohony }\end{array}$ & 4 \\
\hline $\begin{array}{l}\text { - vysvětlí princip činnosti jednotlivých } \\
\text { druhů pístových spalovacích motorů } \\
\text { - seznámí se s požadavky a zvláštnostmi } \\
\text { hybridních motoro̊, je poučen o bezpeč- } \\
\text { nosti a deaktivaci akumulátorů } \\
\text { - rozliší jednotlivé druhy konstrukce hyb- } \\
\text { ridních pohonů }\end{array}$ & $\begin{array}{l}\text { 2. Pístové spalovací motory } \\
2.1 \text { Čtyřdobé zážehové motory } \\
2.2 \text { Dvoudobé zážehové motory } \\
2.3 \text { Čtyřdobé vznětové motory } \\
2.4 \text { Rotační pístové motory } \\
\text { (Wankel) } \\
2.5 \text { Hybridní pohony }\end{array}$ & 6 \\
\hline $\begin{array}{l}\text { - zná konstrukci jednotlivých částí písto- } \\
\text { vých spalovacích motorů; } \\
\text { - zná způsoby kontroly, postupy demontáže } \\
\text { a montáže, seřízení jednotlivých částí } \\
\text { motorů a jejich typické závady } \\
\text { - zná účel a princip činnosti přeplňování } \\
\text { motorů }\end{array}$ & $\begin{array}{l}\text { 3. Konstrukce, diagnostika a opravy } \\
\text { motorů } \\
\text { 3.1 Pevné části } \\
\text { - blok motoru, válce } \\
\text { - hlava válců } \\
\text { - kontrola, opravy } \\
3.2 \text { Klikové ústrojí } \\
\text { - písty } \\
\text { - ojnice } \\
\text { - klikový hřídel } \\
\text { - kontrola, opravy } \\
3.3 \text { Ventilový rozvod } \\
\text { - druhy } \\
\text { - hlavní části } \\
\text { - kontrola, seř́izení, opravy } \\
3.4 \text { Rozvody dvoudobých motorů } \\
3.5 \text { Přeplňování motorů } \\
\text { - turbodmychadla } \\
\text { - mechanické kompresory } \\
\text { - proměnné sání }\end{array}$ & 22 \\
\hline $\begin{array}{l}\text { - popíše konstrukci mazacích a chladicích } \\
\text { systémů }\end{array}$ & 4. Mazání a chlazení motoru & 8 \\
\hline $\begin{array}{l}\text { - zná možnosti regulace soustav } \\
\text { - rozumí principu činnosti spalovacích } \\
\text { turbín }\end{array}$ & $\begin{array}{l}\text { 5. Spalovací turbíny } \\
5.1 \text { Hlavní části } \\
5.2 \text { Princip činnosti }\end{array}$ & 2 \\
\hline
\end{tabular}


Žák: „Nejprve se otvírá sací ventil a začíná..." (popisuje činnost motoru, učitel opravuje a povzbuzuje $\mathrm{k}$ výkladu, žák pomalu a nejistě pokračuje). „Zkusíme ještě jednoho žáka, třeba se to časem naučíte všichni." Vyvolá dalš́ho, který právě nedával pozor. Ten začíná znovu s pomocí učitele.

9:05 Učitel: „Nalistujte si v učebnici stranu 45 a zapište si: Pevné části motoru, Válce“ (zapíše fixem na tabuli včetně stránky a data $s$ č́slem hodiny). „Z předchozích hodin známe pojmenování ćástí motoru. Které to jsou?"

Žáci: „Pevné a pohyblivé.“

Ucitel: „Pevné, klikový mechanismus, rozvody a př́slušenství motoru. Které jsou ty pevné?“

Žáci: „Hlava, blok, válce, kliková skřrin a vana."

Učitel doplní: „Víko ventilů. A dnes začneme podle učebnice Válce." (Promítne obrázek a na tabuli zapíše „Účel“.)

Učitel: „Jaký je účel válcư?“”

Žáci podle učebnice a z dřívější znalosti odpovídají.

Učitel zapisuje a upřesní:

- Zachycení tlaků.

- Tvoří spalovací prostor (s pístem a hlavou).

- Vede píst.

- Odvádí teplo.

(Řekne: „napište si“ a počká.)

Učitel: „Jaké jsou požadavky na válce v motoru?"

Žáci odpovídají a učitel píše na tabuli.

Požadavky:

- Pevnost a odolnost proti namáhání (komentuje: „uvědomte si, že vede píst, dobré třecí vlastnosti")

- Odolnost proti korozi a opotřebení (komentár: „spaliny a na druhé straně chladicí kapalina“).
- Dobrá tepelná vodivost (nepiše, komentuje: „odvádí teplo z pístu přes pístní kroužky“).

Učitel zopakuje a zeptá se, jestli všechno mají napsáno, počká. „Nebo si to vyfotte na mobil,“" (odstoupí).

Učitel promítne obrázek bloku motoru s chlazením vzduchem, smaže tabuli, říká a píše: „Válce chlazené vzduchem. Kde se používajî?"

Žáci: „Motocykly, Brouk VW, Tatra.“

Učitel: Prochází mezi lavicemi: „Proč se už nepouživajíi?" A odpoví si - napiśse: „hlučné, prostorově náročné“.

Učitel se ptá: „Proč se přece jenom používajíi?"

Žáci: „Nemusí se dolévat kapalina, jednoduchá konstrukce.“

Ucitel: „Vysoké teploty, pamatujete Hanzelku a Zikmunda na poušti? Jak se to řeší dnes, aby nevařila voda?“

\section{Žáci nic.}

Učitel: „Přetlak v soustavě jako Papinův hrnec, budeme brát $\mathrm{v}$ chlazení. A kapalina s vyšším bodem varu než voda. Vodu dnes použít nesmíte. Navíc způsobuje korozi." Učitel se vrací k tabuli: „Napište si: válce chlazené kapalinou." A promítne vložený válec.

Učitel: „Máme obvykle litinové vložky válců v bloku z hliníkové slitiny." Napíše na tabuli: „Mokré a suché zalisované." Promítne blok se zalisovanou vložkou.

Učitel: "Jak se to opraví?"

Žáci: „Vylisuje se to.“

Učitel odporuje: „Bývají i zalité, musíte odfrézovat a potom vložit studenou trubku do zahřátého bloku. Jako ložiska, to jste už určitě dělali.“"

\section{Žáci přikyvují.}

9:20 učitel promítne litinový blok válců bez vložek: „A jak se opraví toto?“ 


\section{Žáci: „Výbrus“}

Učitel: „Správně, převrtání na opravárenský rozměr i s jiným pístem. Po kolika setinách je výbrus?“"

Žáci: ,0,25 mm.“

Učitel napíše: „Výbrus první

$$
\begin{aligned}
& \text { I. }+0,25 \\
& \text { II. }+0,50 \\
& \text { III. }+0,75 \mathrm{~mm}
\end{aligned}
$$

Zapište si. A na nákladních vozech jsou větši průměry vrtání, tak je výbrus po $0,5 \mathrm{~mm}$."

Učitel zapišse $0,5 \mathrm{~mm}, 1,0 \mathrm{~mm}, 1,5 \mathrm{~mm}$ a zdůrazní: „Výbrus, opravářský rozměr. Dnes se moc nepoužívá, měníme vložky a písty za originální.“

Učitel: „Zapišste si: třídění válců prvovýroba“ (napíše na tabuli další odrážku). „Tř́ídy válců a pístů $\mathrm{A}, \mathrm{B}, \mathrm{C}, \mathrm{D} \ldots$ po setinách $(0,02 \mathrm{~mm})$.“

Učitel se zeptá: „Jaké jsou to vložky?“

Žáci nechápou, učitel napíše: „Mokré vložky válcư“ a promítne vložku válců v bloku s přesahem.

Učitel se ptá: „Jak je utěsněna vložka v bloku a oproti hlavě? Měrili jste to na dílně? A jak a kolik?"

Žáci: „Měděné podložky a těsnění pod hlavou."

Učitel: „A co je to utopená vložka? Co takhle přesah?"“

Žáci: „Musí tam být dvě desetiny přesah.“

Učitel: „A jak to změríme?“ Odpoví si: „Ocelovým pravítkem a listovými měrkami. Viděli jste? (a načrtne vložku s přesahem a okótuje přesah).

Učitel: „Pochopili jste náčrt?“

9:30: Žáci souhlasí. Učitel smaže tabuli a napíše: Nikasil

Alusil

Plazmový nástřik
Učitel: „Kdy se použivá toto?“”

Žáci moc nereagují, učitel promítne obrázky a komentuje: „Úprava bloku $s$ válci z hliníkové slitiny. Lze použít i na opravu poškozených válců."

Učitel: „Máte to i v učebnici na straně 46" (projde třídou a kontroluje otevřené učebnice). „Podívejte se.“ Promítne obrázek s honováním. Napíše: HONOVÁNÍ a načrtne hrubě povrch i na tabuli. Vezme vložku válce a ukáže vnitřní opracování.

Učitel: „Tak vypadá dobrý nový válec. Proč není hladký?'“

Někdo z žáků se ozve: „Mazání.“

Ucitel: „Výborně, zůstává tam mazací film pro pístní kroužky. Sice máte větší spotřebu oleje, ale nezadře se motor. Naopak až se válec vyleští, je už na výměnu, a ne dobře zajetý, je dobře opotřebený. A dá se to udělat doma?"

Žáci: „Ne.“

Učitel: „Ale můžete se setkat s někým, kdo jakoby generálkuje motor výměnou pístních kroužků, takzvané přetěsnění. Není to úplně správné, někdy to prodlouží život starému motoru."

Učitel prochází mezi žáky: „Tak za chvíli zvoní, zopakujeme si dnešní látku. Co je to přesah?"“

\section{Žáci odpoví.}

Učitel: „Jaký je rozdíl mezi prvním výbrusem a áčkovým válcem?“

Někteří žáci částečně reagují, učitel napovídá: „Který je opravárenský po 0,25 mm?“

Žáci: „Aha.“”

Učitel: „Děkuji vám za pozornost a př́šstí hodinu budeme brát hlavu válců a spalovací prostory. Chce se někdo na cokoliv zeptat?" Chvíli probíhá diskuse na opravářské téma.

9:40 zvoní 